\title{
Roundtable
}

\section{Is Public Management Neglecting the State?}

\author{
BRINT MILWARD, ${ }^{*}$ LAURA JENSEN, ${ }^{* *}$ ALASDAIR ROBERTS, ${ }^{* * *}$ \\ MAURICIO I. DUSSAUGE-LAGUNA, ${ }^{* * * *}$ VERONICA JUNJAN, ${ }^{* * * * * *}$ \\ RENÉ TORENVLIED, ${ }^{* * * * *}$ ARJEN BOIN, ${ }^{* * * * *}$ H. K. COLEBATCH, ${ }^{* * * * * * *}$ \\ DONALD KETTL, ${ }^{* * * * * * *}$ and ROBERT DURANT*********
}

Public management is a domain of research that is now roughly three decades old. Researchers in this area have made important advances in understanding about the performance of public organizations. But questions have been raised about the scope and methods of public management research (PMR). Does it neglect important questions about the development of major institutions of the modern state? Has it focused unduly on problems of the advanced democracies? Has it made itself irrelevant to public debates about the role and design of government, and the capacity of public institutions to deal with emerging challenges? This set of eight short essays were prepared for a roundtable held at the research conference of the PMR Association at the University of Aarhus in June 2016. Contributors were asked to consider the question: Is PMR neglecting the state?

Editors' note. This set of eight short commentaries were prepared for a roundtable held at the research conference of the Public Management Research Association at the University of Aarhus in June 2016. The question posed to all of the participants in this panel was whether the domain of research known as public management is neglecting the state. The question arises because of concerns about the limitations of contemporary public management research. The contributors to this roundtable generally agree on the need for a reconsideration of the aims and methods of public management research, although they do not all agree that a new focus on the state is the best way to redefine the domain. As it stands today, these contributors suggest, public management appears to neglect big questions about the structure of political power, the emergence and evolution of public institutions, and the fostering of public support for the exercise of authority. Developed mainly within a small set of wealthy and consolidated democracies, public management research may be premised on assumptions about state sovereignty, capabilities, and legitimacy that are not tenable in most other countries-and are perhaps increasingly untenable in the advanced democracies as well.

\footnotetext{
*University of Arizona

**Virginia Polytechnic Institute

***University of Missouri

****Centro de Investigación y Docencia Económicas

*****University of Twente

******Leiden University

*******University of New South Wales

********University of Maryland

$* * * * * * * *$ American University
}

Governance: An International Journal of Policy, Administration, and Institutions, Vol. 00, No. 00, Month 2016 (pp. 00-00).

(c) 2016 Wiley Periodicals, Inc

doi:10.1111/gove.12201 


\section{Beginning a Dialogue between Two Non-Intersecting Worlds-H. Brinton Milward}

The field of public management is incomplete because it ignores basic questions about the capacity and purpose of the state. It assumes that all states are alike-that Mexico is just like the United States, for example-and that all states can perform certain basic tasks adequately. This is a mistake. Public management research needs to treat the state as a variable rather than a constant. It needs to address basic questions about the state along with the administrative questions - on topics like personnel, budgeting, contracting, service provision, and regulation-that have historically been the purview of public administration.

About 30 years ago a cadre of young scholars (the writer included) began a movement to reorient public administration toward "the study of public management." This was a movement that had two goals: to break with the tradition of public administration, especially in its normative aspects, and also with behavioral political science. The belief was that the new field should be based on sound empirical study of the structure and functioning of public organizations.

This approach had certain implications about what the "big questions" were in the field. It also had implications about what the level of analysis was (managers, organizations, and programs) and also carried with it some assumptions about preferred method of inquiry. There is no arguing with the success that the public management movement has had in the United States and around the world. Whether in Australia, New Zealand, Great Britain, China, Korea, the Nordic countries, most of Western Europe, and Canada, this is the dominant mode of research in public administration. It has made public administration much more of a social science than it was before. Through New Public Management, it has had policy impact as well.

But this success has not been without its cost. The big questions in public management are not really that big-and meanwhile really big questions about state capacity and legitimacy go largely unaddressed by leading researchers and journals in our field. For example, are the questions that we are asking in the field of public management relevant in a world where international NGOs provide more public services in a country like Liberia than its government does? And what does "public service motivation" mean when whole service systems like mental health are privatized? Similarly, what relevance does public management research have when the U.S. military relies on contractors who are authorized to use deadly force under certain conditions, as in the recent wars in Iraq and Afghanistan?

Donald Kettl and I began a conversation about the limitations of public management research in 2013. This led to a plenary panel at the Public Management Research Conference at the University of Minnesota in 2015 and a workshop at Hong Kong University in 2015. In both cases we asked the following questions.

Are the instruments of public administration and governance, especially instruments like contracts, partnerships, networks, and other alliances, outrunning the ability of governments to control them? What are the implications for legitimacy when governments are unable to control and monitor those who act in their name? As increasing use is made of proxies to advance the goals of the state, is the state's governance capacity and legitimacy being significantly reduced? What kind of state is needed in order to ensure appropriate capacity and more trust in a stronger pursuit of the public interest? These questions focus on actors (who is doing what), institutions-organizations (how strategies and tactics of government connect policy with the people), and events (how performance problems and political developments shape the strategies of political leaders and the views of citizens). What is the ecology of the interlocking forces involving actors, institutions, and events in governance? 
This last question is particularly important. A state and the forces and interests that surround it can be conceived of as an ecology involving laws, institutions, and individuals and groups coming together in a policy domain-for example, veterans affairs. (The concept is drawn from Norton Long's (1958) classic article "On the Local Community as an Ecology of Games.") I have adopted an ecological approach in my own work on dark networks that are composed of nonstate actors who are pursuing criminal or illegal ends. The same approach is also used in my work with Ron Brieger on the emergence of a "multinodal world," in which states are often as concerned with the behavior of nonstate actors such as international corporations or terrorist networks, as they are with other states (Milward and Breiger 2014). The ecological approach is concerned with the distribution and use of power, and for this reason it does not fit well within public management research as it is usually defined. Power is rarely considered as a variable in public management, because it is believed to be hard to measure and incorporate into quantitative research, except as perhaps resource dependence; however, there are ways emerging to include power in research designs (Joosse 2015). We believe that new methods of network analysis can capture the nature of this ecology so that rigorous research is possible (Milward and Breiger 2014).

If attention to power is one reason for reviving the link between public management and the state, a second is an explicit examination of the state over time. Here public management has little to offer. Francis Fukuyama (2015) has written about the decay of the nation state, primarily the decay of the democratic capitalist systems of North America and Western Europe caused by their inability to adapt to changing circumstances. His critique focuses on two elements. First, governments are trying very hard to do things they do not know how to do very well with instruments they do not fully understand. Second, elections and representative institutions appear to be eroding the ability of governments to govern.

What can be done to broaden the scope of public management research? From the layers of the intergovernmental system to policy domains like defense, education, and health, there is a need to study state activity over time to see whether structures that have been created to produce services have improved or declined in their ability to deliver services. The study of how the hollow state of mental health in Arizona did over time is one example (Milward et al. 2010). At the same time, adopting a multinodal approach means acknowledging that the instruments of governance are in the hands of many actors inside and outside of government (Milward and Brieger 2014). Governments even outsource the use of force to warlord militias (like those in Afghanistan), or to corporate armies (like the contractors used in Iraq). Instruments of governance like contracts, partnerships, and alliances are often viewed as ways of outflanking slow-footed bureaucracies that are unable or unwilling to adopt modern business methods. Of course, in some cases, involving the private and nonprofit sectors in helping governments deliver better public services can be a good thing. However, good things carried too far can have bad effects. If not carefully designed, the privatization of public services can outrun the ability of governments to control them. The question of legitimacy is also critical when tasks are delegated to nonstate entities. Political principals can transfer power to their agents within limits set by law, but they cannot transfer legitimacy in the same way.

The answer to governing complexity is not just the adoption of modern management techniques. Today we are confronted with the bigger challenge of rethinking what it means to be a state. This requires serious thought about what we can expect from governments, in the light of such discussions as those by Bobbitt (2002) on the passing from the nation state to the market state, and Fukuyama $(2011,2015)$ on the 
tendency of government institutions to decay. This is a call for public management scholars to join the debate about these bigger questions.

\section{Three Neglected Concepts: State Capacity, Sovereignty, and Legitimacy-Laura S. Jensen}

Almost half a century ago, J. P. Nettl (1968) exhorted social scientists to rescue the concept of the state and make it more central to their scholarship. Many efforts to bring the state "back in" have been made since then, primarily by "new" historical and rational choice institutionalists in the fields of political science, sociology, and economics. These efforts have yielded important empirical and theoretical insights. However, there is still much work to be done, because the ability to capably craft and implement public policy - especially in the face of complexity-hinges upon three core attributes of the state that typically are underspecified, muddled, or neglected in much contemporary public management research: state capacity, broadly defined; sovereignty; and legitimacy. In the paragraphs that follow, I provide a sketch of what these attributes are, discuss how they are meaningfully distinct, and suggest why focusing more careful attention to them in public management research is vitally important.

To begin with, government and state are not synonymous, though they certainly are associated intimately. As I previously have argued (Jensen 2008, 381), government signifies the structure and function of public institutions, their ability to make legally binding decisions, and their authoritative implementation of those decisions and the allocation of values via policy and administration (Kettl 2002, xi; Raadschelders 2003, 4). The state, by contrast, is a more amorphous composite-what Nettl $(1968,562)$ called a summative collectivity $(1968,562)$ - that may (and typically does) involve non-governmental actors, entities, and institutions along with government in its activities. It is a configuration of multiple dimensions that interrelate distinctively and contingently in space and time (Nettl 1968). Fundamentally, a state's raison d'etre is that of defining and pursuing the common interests of a given society. States are not merely governmental institutions, but aggregate entities with collective purposes that vary geographically and temporally.

State capacity is similarly multidimensional. Though we might very generally define it as the degree to which a state is able to conduct the public affairs of a given polity, we might more usefully imagine a complex of complementary state capacities, all of which are necessary both individually and in combination. These include (but are not limited to) extractive capacity (the state's ability to secure and mobilize resources sufficient to carrying out its purposes), coercive capacity (the state's ability to control behavior through the threat or use of legal sanctions or force), administrative capacity, defensive capacity, and constitutive capacity (the state's ability to deploy symbols and narratives to facilitate national consciousness, public consensus, and the like). The requisite balance among and between state capacities necessarily will vary spatially and temporally.

The term governance should be understood to embrace all of the actors, organizations, and institutions, public and nonpublic, involved in structuring polities and their relationships, whether they lie within sovereign states, without, or somewhere in between (Ladeur 2004, 10-18). It also encompasses the intricate ecology of political culture, rules, values, beliefs, principles, goals, interests, powers, and cleavages (Olsen $2006,7)$ that shape the historically and geographically situated contexts in which governance occurs. Used in this way, governance reflects the restless, kinetic nature of states and stateness, and evinces the fact that both are constituted dynamically 
through everyday practice. The state is intimately involved in governance whether or not government per se is merely "steering."

Finally, sovereignty, the state's claim to ultimate political authority within a political community (and, typically, a geographic territory), is central to policy implementation regardless of the organizational arrangements involved. So, too, is legitimacy: the perception by citizens that the state's actions are appropriate, and their acquiescence in its claim of sovereignty. Absent public attachment to the goals and purposes of the political community that the state represents, sovereignty is undermined, and state capacity with it. Both sovereignty and legitimacy and their production thus are vital to successful public management.

That other public management scholars will not agree with the definitions I offer only emphasizes the need for closer attention to the state and its core attributes. Some of the problems engendered by our lack of attention to them are significant. The tendency of some scholars to use the term governance as a synonym for government, for example, has allowed large questions of public management (such as how, why, and with what consequences social welfare programs affect the political incorporation of citizens) to be bypassed in favor of smaller questions about the structure and functioning of public organizations (such as whether and to what extent particular jurisdictions contract out for welfare-to-work programs). Other scholars meanwhile have perpetuated a definition of governance as the contemporary reliance upon nongovernmental mechanisms for achieving public purposes. These definitions not only are at odds with each other, but also with broader and more historically informed understandings.

Still other scholars conflate governance with the capacity to deliver public services. Beyond inducing even more conceptual problems, this also extends a literature that is already excessively focused upon service delivery. Service delivery is doubtless a vitally important task, and it has been a core concern of several recent public sector reform movements. Nonetheless, it is only one of the state's many responsibilities, as evinced by the complex of state capacities articulated above. In addition to delivering services effectively and/or efficiently, public management also involves such critical tasks as the conduct of international relations, deterring and punishing criminality, and ensuring equity. The capacity to execute these responsibilities should also be central concerns of public management scholars.

Public management scholars also need to bring the state "back in" to their analyses so that they can properly assess the impact that nonstate actors have on nation-states and the international system. Historically, states have always been concerned with the behavior of nonstate actors, but the scope and significance of the latter's activities have grown over time as the world has become more highly interconnected. Nonstate actors are not merely potential partners for the delivery of public services. Hostile nonstate actors such as terrorist or criminal organizations can pose serious threats to the sovereignty and legitimacy of states, and create the need for those states to create new forms of capacity, for example, in the areas of defense, intelligence, and policing. For example, consider the public management dilemmas currently posed by ISIL and its affiliates.

Public management scholars also need to better consider how state capacity, sovereignty, and legitimacy figure within nations. As scholars of religion, gender, history, and family relations long have demonstrated, governance may be private as well as public. The ascriptive hierarchies of gender and race embedded in the actions and achievements of the American state in its formative decades emanated significantly from nongovernmental sources (Jensen 2003; Smith 1997). They also were a feature of government and public law, inherited via colonial precedent and reinscribed in the 
statute books of the new nation-to the extent that, in stark contrast to other nations, the U.S. permitted the legal ownership of persons. Although such repressive practices as slavery, Indian "removal," and coverture formally have been eradicated, their legacies endure. Recent events have only too horribly shown, for example, that racism and associated brutality and trauma are alive and well in the United States. The persistence of these wicked problems in the face of democratic principles and constitutional guarantees raises profound questions about the American state and public values, as well as about the distinctive roles that government and public managers have to play in shaping those values.

Public management scholars also need to revive considerations of state capacity, sovereignty, and legitimacy with respect to the practice of contracting out for the performance of public functions. Though public-private governance schemes of this sort are far from new either in the U.S. or abroad, their overall scope and, moreover, the ends they are being put toward indeed are novel and perplexing. The use of contractors in international conflicts raises particularly provocative questions because foreign wars traditionally have been comprehended as core exercises of sovereignty pitting nation-state against nation-state in a most drastic form of international relations. Leaving aside the issues of armed conflicts with nonstate actors and of conflicts in which war has not formally been declared, public management scholars must still contend with the implications of mongrel fighting forces made up of military personnel and privately employed mercenaries and "support" staff. When problems occur, as in the U.S. engagement in Iraq, it is the state that is called to account. Questions about U.S. responsibility for the killing of citizens in Baghdad's Nisour Square, for example, linger unresolved even after the 2014 convictions of several Blackwater security guards. When questions such as these remain unanswered, the state loses some of its legitimacy, and sovereignty and capacity are undermined.

In sum, we cannot afford to ignore, dismiss, or neglect the state if we are to answer big questions of contemporary public management. The state is profoundly consequential both conceptually and practically regardless of trends in scholarly research (Nettl 1968). It is time to bring it-and the associated concepts of capacity, sovereignty, and legitimacy-back in to public management research.

\section{Public Management: A Flawed Kind of Statecraft-Alasdair Roberts}

"Even the most abstract works of political theory are never above the battle," the historian Quentin Skinner has observed, "They are part of the battle itself" (Skinner 2008, xvi). The same can be said about modes of inquiry such as public management research (PMR). PMR ought to be understood as the product of a particular phase in the development of some advanced Western states. But this fact is rarely acknowledged.

PMR emerged in the early 1980s and was thoroughly institutionalized over the next 30 years. Today, PMR has these features:

- Its work appears in a small number of journals published in the United States and the United Kingdom. The articles in these journals are disproportionately concerned with aspects of management in a few wealthy democracies: notably, the United States, the United Kingdom, Australia, New Zealand, Canada, the Netherlands, Belgium, Denmark, Norway, and Sweden (Hou et al. 2011, i47-i48). 
- It is particularly attentive to management problems within agencies providing social services, and relatively inattentive to functions such as defense, law enforcement, judicial administration, legislative administration, and electoral administration.

- It is not usually concerned with basic structural questions such as the design of personnel or financial systems, systems for executive oversight and coordination, or systems for assuring the legality of administrative action. It is generally taken for granted that these systems exist and that problems of corruption and improper political influence over administration have been minimized.

- It has a propensity to prefer quantitative research based on data that are generated by the administrative processes of public agencies. (This assumes that there are administrative processes capable of generating these data.) This is widely viewed as the most reliable way of "testing" propositions about management.

Two events led to the emergence of PMR and help to explain its distinctive features. The first was the expansion of the American welfare state in the 1960s. By that time, basic problems relating to the organization of government had been resolved in the United States. Systems of personnel and financial administration, executive control, and judicial review were well established. For this reason, there was great confidence about the ability of government to solve public problems, guided by specialists in the new policy sciences. Schools of public policy were soon established across the United States. Economists often played a prominent role within the faculties of these schools (Yates 1977, 364).

By the mid-1970s, however, there was a widespread appreciation that many programs established during the surge of the 1960s had failed to achieve their objectives. This was interpreted as the result of inattention to problems of compliance and coordination within a sprawling federal system. Soon public policy schools began to put more emphasis on problems of implementation and management, focusing mainly on social programs, and using methods of inquiry that were often sometimes designed to deflect criticism from the economists who dominated the faculties of those schools (Elmore 1986, 70). By the 1990s, faculty in some old-style public administration programs began to emulate the focus and methods of management specialists within public policy schools, with whom they were increasingly in competition.

The second event that shaped PMR was the period of state retrenchment following the collapse of the Western postwar boom in the early 1970s. In the United Kingdom, the pivotal moment was the humiliating appeal for assistance from the International Monetary Fund in 1976; in the United States, it was the California tax revolt of 1978. For the next 30 years, politics in these two countries was preoccupied by efforts to contain the cost of public services. One of the key concepts within PMR-New Public Management (NPM) — was born out of this search for more efficient ways of managing public services (Hood 1991). Center-left politicians were eager to find ways of making government "work better and cost less" so that they could counter conservative demands for complete abandonment of some public services (Gore 1993).

In sum, we can think of PMR as an exercise in statecraft-that is, part of a project of renovating public institutions to accommodate the needs of the moment. However, PMR has rarely viewed itself in this way. And because it has not been anchored by sensitivity to context, PMR has tended to have an imperialistic quality. Some writers have even heralded the advent of a "global public management movement." Generic 
"questions of public management" are frequently enumerated, with the assumption that the whole world shares an equal concern for these questions. NPM has often been used as the framework for homogenizing national conversations about governmental reform. In the 1990s and early 2000s, for example, there were many studies that examined how specific countries were pursuing NPM-style reforms and whether the world was converging on the NPM model. Of course, this was a backward way of diagnosing governance challenges in most countries. The practices of other countries became significant only insofar as they reflected or diverged from the preoccupations of countries like the United States and the United Kingdom.

Certainly, non-Western countries face many challenges that can be fit within the public management paradigm. But this does not mean that the main problems of statecraft in these countries have to do with public management. On the contrary, the administrative challenges confronting most national governments are often distinct from those confronting the Anglo-American and northern European democracies. Territory is not secure, internal order is not established, police are corrupt, elections are manipulated, the judicial system is broken, taxes cannot be collected, political leaders cannot formulate plans, and the bureaucracy cannot execute them. Sometimes, the basic idea that there should be a sphere of administration that is free of political, ethnic, or familial influences is not established. Statecraft in these countries is preoccupied with building the foundational elements of state capacity that are taken for granted in the advanced democracies.

Such problems are not unknown in the West. As it happens, the field of public administration came into being in the United States as part of the project of building these foundational elements. In other words, old-style public administration was also an exercise in statecraft, suited to harsher conditions. But public administration was overthrown by public management after the 1980s. Today, the state-building problems of non-Western countries are more likely to be addressed by academics in political science or economics. Public management does not have much to say about them.

Nor does public management have much to say about recent problems with state performance in Western countries. In the United States, for example, there are complaints about the "dysfunctionality" of government, that is, the apparent inability of the establishment to respond coherently to current and looming challenges (Fukuyama 2014; Mann and Ornstein 2013). There are also complaints about a pattern of "endemic failure" in government programs that threatens to undermine confidence in democracy (Schuck 2014; Volcker Alliance 2015). And there is an observed need to build new forms of state capacity to deal with unfamiliar challenges like climate change. Again, there was a time when all of this would have been regarded as the natural terrain of scholars in public administration. Much of the public administration literature of the Progressive and New Deal eras was written in response to similar problems of state failure. But PMR, a mode of inquiry built for a different time, does not have much to say about these topics.

The broad aim of public administration is the construction and renovation of public institutions to fit the needs of the moment. Because circumstances change, we should expect that every generation will have a distinctive understanding about priorities and strategies for state reform. PMR has been viewed as an umbrella concept that could displace public administration entirely (Lam 1997, 405-406). But PMR is just an instantiation of the broader project of public administration. It is a form of statecraft that made sense in a few advanced democracies in a few decades at the end of the twentieth century. 


\section{The Limits of Public Management Research in Latin America-Mauricio I. Dussauge-Laguna}

For academics and practitioners in developing countries, public management research (PMR) has been a refreshing source of knowledge, but also one with limited relevance. PMR has provided ideas, concepts, and propositions that help to better describe and understand certain government features and patterns of change in regions such as Latin America. Yet PMR, at least in its main version (i.e., U.S.-based, quantitatively oriented, theory-testing focused), is interested in questions that, quite simply, do not reflect the main preoccupations or the politico-administrative contexts faced by public officials in these countries.

Since its arrival in the early 1990s, PMR has been a welcome addition to public administration (PA) studies in countries like Mexico. The idea of a cadre of officials that could be labeled "public managers" seemed both interesting and promising. Faced with a dual political legitimacy-economic crisis, some scholars thought the Mexican state could use a new breed of public managers, more strategically oriented and less change averse than traditional public servants (Cabrero 1997). The translation into Spanish of Barry Bozeman's Public Management: The State of the Art and All Organizations Are Public immediately entered the curricula of courses focused on PM, as well as of those dedicated to PA more generally. Discussions of strategic planning and quality management were received with a bit more skepticism in some academic circles (e.g., public universities), yet they were also seen by others as a useful source of ideas for reconceptualizing the Mexican/Latin American style of governing: disorganized, inefficient, and not at all customer friendly (Aguilar 2006). International debates on "New Public Management" (NPM) provided the vocabulary and empirical examples needed to make sense of reform initiatives and better frame criticisms regarding their mixed (when not outright poor) results (Arellano 2010; Pardo 2009).

From a practical standpoint, PMR concepts and propositions have spread widely. Since the mid-1990s, official plans and modernization manifestos alike have been sprinkled with terms such as "mission," "vision," and "strategic goals." There have been a variety of attempts to "improve service quality," including tropicalized versions of the United Kingdom's citizen charters and U.S.-inspired innovation projects. Management for results (MFR) ideas and practices (e.g., performance indicators, program assessments, performance audits) have slowly but surely disseminated throughout government agencies and policy sectors. Nowadays, the concept of "public value" advanced by Mark Moore is frequently invoked in government meetings (even if not always reflecting the meaning intended by its author).

But if PMR has broadened academic debates and informed public sector practices in the region, it has never reached the prominence its original sponsors envisioned, as Brint Milward observes in this roundtable. First of all, there is the issue of limited academic capacity and skills: Previous generations of PA scholars were not trained in the kind of quantitative methods that the American style of PMR privileges. This has been changing in recent years, but leading scholars in the field still prefer to produce mostly qualitative works. Furthermore, PM has never been considered an independent discipline. As in the case of public policy studies (which, incidentally, have become far more influential), PM has always been understood as one of a variety of approaches that are part of the broader PA field.

Leaving aside epistemological and theoretical reasons, scholars in the region have not faced the same favorable conditions as their colleagues in the United States or Europe. The main issue has not been one of funding (even if that is often a problem) 
but of information availability. It is not easy to find or have access to reliable data sets about school districts, medical services, administrative decisions, or judicial outcomes, just to mention some common research topics. Nor is it always possible to interview key policymakers/public managers, many of whom still do not like the idea of being questioned about their work, let alone their decisions. When conducting a research project on civil service reform 15 years ago in Mexico, I was told I could not access federal personnel management data because the agency head liked to keep those figures for his private use. More recently, despite several requests, it was impossible for me to interview key senior budget officials for two research projects (one on federal budget management, the other on MFR reforms in a state government). Things are changing with freedom-of-information legislation, the open data movement, more professionalized civil society organizations and journalists, and the willingness of a growing number of committed public officials. Yet we are still far away from a "Texas" or "the Netherlands" level of information availability.

There are also structural reasons why PMR has not flourished in Latin America in the way it has in other jurisdictions. Historically, national administrations in the region have evolved within a highly politicized environment, with the state as the leading institution that mediates social conflicts and economic disputes. Latin American PA scholars have thus always looked at public administration/policy/management topics from a political perspective, in which public managers are expected to negotiate patronage pressures and politicized service provision. This kind of politicization is substantially different from the one depicted in managerial analyses of the authorizing environment. In fact, academic efforts aimed at describing or explaining administrative developments can hardly rest on the equation noted by Brint Milward, "managers + organizations + programs." They usually need to add variables such as party politics, ideology, and (often) corruption.

However, perhaps the main issue that PMR has faced (and will continue to face in years to come) is that neither Latin American scholars nor practitioners find enough guidance or answers in it. For the first group, PMR does not say much about how new democracies should deal with bureaucratic legacies (Cejudo 2015), how effective public sector accountability and anticorruption systems may be designed, how to avoid recurrent decentralization failures, how to explain the very slow progress of merit-based administrations, or what to expect from new nonmajoritarian institutions. In fact, it is to political science, public policy, and PA debates (and not to PMR) that scholars turn to make sense of these "big questions."

To Latin American public servants (including those at the management level), PMR does not have enough to say either. Strategic planning, quality management, and personnel management discussions certainly provide them with insights and tools for becoming better managers. Contemporary network management and collaboration studies also have the potential to broaden their perspectives and skills. On the other hand, it is difficult to apply MFR principles when good internal monitoring systems and databases are scarce, to follow performance-based budgeting recommendations when budget allocation processes are unpredictable, to lead and motivate people who lack basic qualifications or fair salaries, or to plan strategically when administrative priorities change frequently according to political conditions. In other words, PMR propositions may not be very helpful for public managers who generally do not face the organizational preconditions assumed by PMR.

How could PMR become more relevant for these countries? While there obviously is not a simple answer to this, three research strategies can be proposed. First, quantitatively oriented theory-testing exercises are very valuable, but they should be supplemented by more qualitative theory-building exercises. (As Ed Page would say, it 
would be nice if we spent a bit more time studying how things really work before we start testing theories.) Second, more cross-national comparative work would be most welcome. Recent scholarship arising from NPM reforms has produced interesting findings. Other management areas could be similarly compared, focusing on both developed and developing countries. Last but not least, we should better link PMR scholarship with the big challenges and trends that are shaping the governance landscape, both internationally and in individual countries. Taking Mexico as an example, topics could include: How can effective public management contribute to reducing poverty, inequality, or crime levels? How should public servants manage in settings where public confidence is low, corruption is widespread, and resources of all kinds are quite limited? What are the skills that public managers require to manage "structural reforms" (which simultaneously introduce merit-based structures, NPMinspired techniques, governance practices, and new regulatory regimes) in fields as diverse as education, energy, telecommunications, tax policy, and elections? Whether future PM scholarship will offer useful insights in any of these fronts is perhaps the biggest question of all.

\section{Sustainable Reforms Are Impossible When the State Is Neglected-Veronica Junjan and René Torenvlied}

Public sector reforms affect two important dimensions of the state. The first is the dimension of government control. In a narrow sense, this dimension is often understood in terms of introducing New Public Management (NPM) and managerialism: new management techniques or procedures that improve the accountability of public servants to the political elite. The second dimension of public management reforms is the dimension of democratic responsiveness, which aims to improve the legitimacy of the exercise of coercive power by the state (Milward and Provan 2000). Public management reforms (but also public management research on reforms) have put too much emphasis on government control and not enough emphasis on democratic responsiveness. In Central and Eastern European countries (CEECs), these imbalances have led to unsustainable reforms, harming the quality of public service delivery and also political stability.

By definition, managerialist reforms do not intrinsically emphasize increased democratic responsiveness. The democratic responsiveness dimension in public management reforms must build on the principle of the trias politica, or the separation of powers. This is taken for granted in the established democratic states, where managerialist reforms started. The situation was very different in the CEECs. Before 1989, society in these countries was captured by the state-in terms of a strong control by economic interests and a corrupt elite, which was represented by a single rule and a dominant party. The role of the state was immense, and the challenge was to reduce that role fundamentally.

The restructuring of the state in this region was shaped by the goal of joining the European Union. The European Councils in Copenhagen (1993) and Madrid (1995) laid out the three dimensions on which the accession efforts were going to be carried out. Political criteria were defined in terms of having functional institutions able to assure democratic representation, respect for the rule of law, and protection of human and minority rights. Economic criteria were operationalized in terms of a functional market economy. Countries were also expected to show the ability to assume the obligations of membership, which was operationalized in terms of developing the administrative and institutional capacity needed to implement EU policy (the acquis communautaire), which was divided in 35 chapters on various policy areas. The 
introduction of public management reforms was an imperative component of the accession process. Emphasis was put on NPM principles, which were thought to solve all perils in the world of administration.

Accession countries were given flexibility in deciding how to meet the criteria established by the European Union (EU). The EU provided a broad range of solutions and encouraged a "mix-and-match" approach. Candidate countries chose what they saw fit for their own context. This was a primarily technocratic exercise, which relied upon experts (both within candidate countries and the European Commission) for the design, negotiation, and evaluation of reform policies. Although reform policies were subsequently forwarded to national parliaments, they were usually adopted without many objections.

The introduction of structural reforms in these countries represented a unique natural experiment in changing both the democratic responsiveness and government control dimensions of governance at the same time. Subsequently, there was a structural lack of balance between these two dimensions, which went by uninvestigated by decision makers and researchers alike. In addition, on both dimensions the results of the reforms were mixed (Drechsler and Randma-Liiv 2015). The research on the reforms focused to a large extent on the managerial aspects of the reform process, and to a decreasing extent on the democratic responsiveness, mirroring the imbalance in reforms. Disparities across politico-administrative contexts started to make a difference in terms of the success of the reforms. Poland, Czech Republic, Hungary, Slovakia, Slovenia, and the Baltic states registered higher levels of success in the progress of negotiation and implementation of the reforms than Bulgaria and Romania. The former group joined the EU in 2004, followed by the latter two countries in 2007. However, the successes of these countries related mainly to developing a modern civil service and to building of administrative capacity. After joining the EU, significant relapses in the reforms were also noted in the CEECs, both in administrative and political areas, raising questions about the sustainability of reforms.

The project of institutional reform encountered two problems. With regard to democratic responsiveness reforms, the paradox was that the state itself was put in charge of reducing its own powers. The technocrats who were responsible for defining reform policies were constrained from taking the principle of the trias politica seriously. As a result, the initial emphasis on the democratic responsiveness dimension of public sector reforms often faded away. The failure of this aspect of reform then created further difficulties. The government control reforms improved the capacity of the government elite to control the state bureaucracy through the introduction of managerialism. However, from the perspective of democratic responsiveness, there was insufficient pressure on the elite to deliver high levels of public service output and quality. Despite the introduction of democratic responsiveness reforms, such as the introduction of institutions to assure democratic representation, and respect for the rule of law, the reforms did not transform public demands into responsive policies. The general public, government representatives, and political parties needed time to learn how to express and evaluate their needs and demands within the framework of the reforms.

As a consequence, the system was unable to produce a high level of public service output and quality needed to address citizen expectations. Expectations were highpartly fueled by the swift introduction of government control reforms. The combination of high expectations and the inability to deliver high-quality services produced, among citizens, widespread feelings of dissatisfaction, as well as perceptions of government corruption and red tape. 
The neglect of democratic responsiveness after the EU accession (in comparison to government control) has not only resulted in public discontent, but it also opened the way for nationalist and EU skeptic movements in several CEECs. These movements further invest in government control rather than in democratic responsiveness-thus reinforcing the preexisting imbalance between the two dimensions of public sector reforms in these countries. Although the state is "back in," in the CEECs it manifests itself primarily in government control. The state lacks the necessary elements of democratic responsiveness that would make the desired reforms sustainable. Consequently, even higher levels of elite capture and public discontent will likely develop. This process will lead to a vicious reform cycle of political instability and reform failures.

The experience of the Central and Eastern European countries during the accession process clearly illustrates the importance of maintaining a balance between the dimensions of government control and democratic responsiveness. The reason is that in order to become sustainable, control-oriented (managerialist) activities must be embedded in a responsive political-administrative system, providing the conditions for reforms to deliver the appropriate level and quality of public services. This important idea has not been given adequate attention in PMR, which was developed in countries where the trias politica was already well established and functioned suitably. One way to ensure that this balance is properly recognized is to give more attention to the way in which the interaction between these two dimensions shapes the role of the state in designing and carrying out reforms. New Public Governance and coproduction perspective only provide a partial answer to this issue. Presenting both as "best solutions" to design and implement reforms would repeat the errors made when introducing NPM. By understanding the mechanisms that govern the interaction between democratic responsiveness and government control, we are more likely to develop reform programs that are sustainable in the long run.

\section{To Manage Major Crises, We Must Understand the State-Arjen Boin}

In recent years, we have witnessed a string of crises that undermine state sovereignty and sap the legitimacy of public institutions. Terrorist attacks, financial breakdowns, deadly epidemics, migration flows, and mega-disasters have stress-tested the state's capacity to accomplish its core tasks-guard its borders and protect its citizens-and have found this capacity wanting. Dramatic renovations are required to buttress the state's capacity to manage large-scale crises and disasters. Unfortunately, public management researchers have little to offer for these much-needed renovations: They do not study the state and have paid scant attention to the performance of public management in times of crisis.

Crises test the mettle of the state's leaders and its institutions (Boin et al. 2016). The state's political and administrative elites must address challenges they rarely face. They must make sense of a quickly evolving situation with very limited information. They must identify critical decisions that should be made at the top, leaving operational decisions to crisis professionals. They must coordinate the actions of actors that do not fit neatly into predefined authority schemes. Furthermore, public leaders face the composite challenge to have all actors in the network communicate the same message, provide citizens with hope and offer visions of a believable future. After the crisis, public managers must facilitate a return to normalcy, account for their actions while learning lessons to prevent similar crises from occurring again. All this happens in an atmosphere of deep politicization, with many seeking to exploit the crisis to their advantage. 
Taken together, the challenge for public managers and political leaders is to minimize the consequences of crisis and to protect public faith in society's key institutions-those same institutions that are essential to the everyday functioning of society. When they fail this test of statecraft, the legitimacy of the state and its institutions suffers as a consequence.

This challenge is especially hard to meet in the case of transboundary crises, that is, threats that cross geographical and policy borders (Ansell, Boin, and Keller 2010; Beck 2008). Transboundary threats emerge from a chain of interdependencies (the world economy, connected infrastructures), which shields them from detection. As it is not clear who "owns" these crises, cross-border cooperation is essential. But it is not easy to align bureaucratic, political, corporate, and national interests in a way that is effective and democratically anchored.

In these transboundary crises, custodians of the state face a vexing dilemma: Should they try to decouple the state from the deeply complex and intertwined "system of systems," with the aim of managing problems on their own, or should they give up sovereignty to enhance the crisis management capacity of transboundary institutions? There appears wide agreement that the growing interconnectedness of economic systems and halting efforts to collaborate in international organizations is eroding the state's capacity to address all those troubling problems facing modern society. In the absence of effective transboundary crisis management capacities, leaders may therefore feel forced to retract: build a wall against refugees or unplug the Internet. Such choices come at the steep price of backing away from international commitments.

Pushing for stronger crisis management capacities in transboundary institutions is often a political bridge too far. But existing capacities do not suffice. Public management research has shown time and again that the capacity of public bureaucracies to deliver critical services is limited in the best of times, and declining, as Don Kettl has warned in this Forum (cf. Fukuyama 2014).

Crises further undermine the state's capacity to deliver. The state's policies and institutions are not designed for quick decision making under conditions of deep uncertainty. The reliance on rules and deliberation, the fortified walls separating policy fields, the lack of adaptation, and improvisation-public bureaucracies are not the best vehicles for a rapid response to an existential threat.

A crisis does, of course, provide the state with exceptional means to overcome these deficiencies. As it happened in Roman times, it happens today: authority is quickly shifted upward to a few selected leaders who have the power to make life-ordeath decisions and reallocate scarce resources. Democratic constraints are lifted to enable quick decision making. In this state of exception (Schmitt 1922), the stewards of the state can do things they could not do in normal times. But this concentration of power does not automatically lead to effective and legitimate crisis management (Hurricane Katrina offering just one painful example).

Public management scholars have been quick to criticize the crisis management performance of public managers. Armed with hindsight knowledge, they readily apply their frame of reference-how governance works in "normal" times-to understanding crisis management. But crises make the patterns and regularities so nicely documented by the public management community disappear like snow before the sun. Crisis management does not resemble the neatly drafted plans for routine emergencies. It is messy and looks chaotic. It is no wonder public management scholars often see, and subsequently denounce, abject failure. In the wake of Hurricane Katrina, for instance, public management scholars offered up the familiar recipe of leadership failure, bureaucratic fragmentation, and red tape; they offered few ideas 
how to actually handle these "mega disasters" and how to govern in "states of exception" (but see Moynihan 2012).

Such ideas are needed more than ever. As modern society is confronted with (or overwhelmed by) threats for which the available capacities, plans, and processes offer no solutions, public managers are forced to improvise and experiment. One might say there is nothing new here: "[T]he nation-state has always struggled to manage large social and economic forces. It does this by building, and constantly rebuilding, the administrative apparatus of government" (Roberts 2015, 4). In crisis, however, such rebuilding must be done in real time. New collaborations and working procedures must be invented on the spot.

Thinking about possible improvements, three questions demand our attention. First, there is the issue of institutional design: How can we build transboundary crisis management capacities that effectively and legitimately negotiate the constraints of sovereignty? Second, there is the legitimate use of extraordinary modes of governance that are placed in the hands of a select group of officials: What are the institutional requirements to ensure both effective and legitimate application of these emergency powers? Third, there is the issue of selection and training of crisis managers: Who should we entrust with this responsibility? What sort of training do these public managers need?

Public management scholars have little on offer. They show limited interest in the state, which is a mere abstraction in most public management studies: Concepts such as borders, political authority, sovereignty, or the monopoly on the use of force rarely feature in their discussions. Judging from public management research, one might conclude that the state has become irrelevant.

Public management scholars do examine the "hands and feet" of the state: its institutions and policy processes, the constellation of public managers, the motivation of public service employees, the dynamics of networks, and the role of nonpublic organizations that do the state's business. Their extensive work on "the public management variable" (DiIulio 1998) has helped us understand the state's capacity to deliver essential services to its citizens in "normal" times. But they do not study how this capacity holds up in times of crisis or how its resilience could be enhanced.

At the same time, the public management community is well positioned to address these questions. Their focus on leadership, public service motivation, organizational capacities, and network coordination is highly relevant. Their appreciation of tensions-between effectiveness and efficiency, action and legitimacy-is particularly helpful. But they will need to translate these insights to the messy world of crisis management. They must develop a conceptual toolkit that provides analytical grip on seemingly chaotic processes.

The public management research community can be of service by expanding its purview to studying how the state can deliver essential services under conditions of crisis. It is time for this community to study the "crisis management variable" and suggest ways to enhance the state's crisis management capacities. The public managers who are trying to save the day are in desperate need of assistance. Here is a clear opportunity for public management research to make a critical impact. All this begins, however, with a pivot toward the state.

\section{The Need for Self-Awareness in Public Management Research-H. K. Colebatch}

"Public management" and "the state" are not discrete objects, but constructs used in the theorization of practice-not just by academic analysts, but also by practitioners and the public, who, in a diverse range of contexts, all seek to "make sense" of 
governing. Following Weick (1979), I focus on the diverse activities that order practice rather than on the apparent producer This outcome comes from a wide array of exercises of governing particular fields of activity, undertaken by clusters of participants in a more or less recognizable "organizational field," which is not so much "the government" as the field of activity to be governed-taxis, for instance, or school examinations, or the milk supply. So the question is not so much whether public management is neglecting the state, or state theory neglecting public management, but how each is being used to make sense, and in particular, the extent to which perceived changes in practice challenge the terms used in these constructs.

The state is an established construct in political science, seen as a distinct entity, coherent, hierarchical, and instrumental, ruling society by the exercise of legitimate coercion, subject to philosophical and economic arguments about the proper relationship between collective, "public" action, and the realm of individual, "private" choice. Public management is a construct labeling a distinctive form of practice, asking (in effect) "how are the functions of government organizations carried out?" - that is, what is distinctive about government organizations as organizations?

Both concepts have been challenged by arguments about the changing nature of governing in some liberal democracies in the late twentieth century. There have been political challenges to the "welfare state" paradigm, arguing that state action could not achieve an optimal outcome, with voices from the right calling for market-like responses to collective action problems, and from the left, demanding more participation. Rhodes (1997) argued that "government" by authoritative directions had been replaced by "governance" by negotiation among self-organizing networks, leaving the state "stateless."

Similarly, public management came under challenge from claims that policy objectives are now pursued through a range of organizations-not only the state bureaucracy, but other levels of government, nongovernment organizations, and corporations, both for profit and not for profit-and that the assumption that there might be a "generic" way of managing these policy responses is now outmoded.

So in both cases, the challenge comes from assertions that the process of governing has changed to include "nonofficials." But this is something that scholars of governing have long recognized. The problem has been to find room for it in the "textbook account" of government, and to relate the conceptual "state idea" to the empirical "state structure" (Abrams 1988). A. F. Bentley subtitled his 1908 The Process of Government "A Study of Social Pressures, and 30 years later, Griffith suggested that a researcher could "obtain a better picture of the way things really happened if [he or she] would study the "whirlpools" of special social interest and problems" (Griffith 1939, 182-183).

This was part of the experiential knowledge of practitioners, but to the extent that academics noticed it at all, it was by way of metaphors- "whirlpools," "gatekeepers ... camped permanently around each source of problems," "policy communities," and so on-which became footnotes to the conventional account of rule by official structures and practices. It seemed that political science found it difficult to come to terms with a perspective on governing in which "the government" (or "the state") is less an actor than an arena, a conglomerate of specialized clusters of participants, with varying degrees of "officialness," each with its own agenda and often in contention with other parts of government.

In the "governing" perspective, organized representatives of the area being ruled are likely to be present in the corridors of power, and the process of rule involves a great deal of negotiation in search of consent from a range of "stakeholders" with varying relationships to the central authority figures. Here, too, the empirical 
evidence seemed to question the textbook account of government as authoritative direction. Government regulations are announced, but turn out to have been sought by the industry. Decisions are announced but do not settle conflicts. Research is commissioned but the findings are ignored. Practices from one context are applied in other, quite different, contexts. Governing is "put together" from disparate elements-and is then described in systematic, authoritative terms.

In some (but not all) countries, political scientists have seen these claimed empirical changes as confirmation of Rhodes's argument that there has been a shift from "government" to "governance." This was soon challenged on both empirical and conceptual grounds (Colebatch 2014), but scholars came to recognize governing as an outcome of interaction, with practice being heavily influenced by action, relationships and norms across the field (e.g., Campbell, Hollingsworth, and Lindberg 1991). This interaction is unplanned but not unpredictable: Over time, the participants and the behavioral norms become clear and are institutionalized.

Moreover, the "governmentality" perspective shows the extent to which governing relies on the presence of "governable subjects," and that this reflects practices and ways of thinking that are established over time and cannot simply be commanded by government-demonstrated recently in Ferguson, Missouri. This turns the focus to shared perceptions of collective needs and appropriate responses to these needs"the governance of problems," as Hoppe (2010) puts it.

So the work of governing is (and always has been) an exercise in the continuing collective management of the problematic. It involves multiple participants, diverse agendas, and multiple forms of order. The continuing interaction generates areas of relative consensus, but these need to be "enacted" through authoritative rituals- the statute, the ministerial statement, the bureaucratic reorganization-to demonstrate (both to participants and observers) that the areas of concern are now "under control." Both "the state" and "public management" are merely formulations in this process, representing (re-presenting) the ongoing, complex, interactive, and ambiguous pattern of activity in a simpler and more normatively acceptable format.

The problem for political scientists and researchers in public management is that their concepts are both analyses of practice, and also part of the practice, and that practitioners-at least in public-may need to assert the reality of "the state" or "public management" in order to legitimize some things and delegitimize others. The task for scholars is to recognize this in their own theorizing.

First, it means recognizing that our concepts are part of the action. Terms like "implementation" are not simple descriptions of action, but validations of the action by locating it within a chain of authoritative instrumental behavior. To say that local police are "implementing" official policy on domestic violence is not so much to describe what they do as to project a meaning onto their practice, highlighting the response to domestic violence over the other things that they do.

It also means recognizing that governing involves more than government programs, whether executed by state bureaucrats or official collaborators. The governing of issues, like child obesity, educational achievement, or workforce participation, involves much more than official programs, and this has implications for the concept of the state and the nature of public management.

It suggests that "state" is an attribution of significance to practice rather than a distinct entity. There are many participants, from a range of organizations with diverse agendas and varying relationships to the political center. Blood donation may be voluntary and run by the Red Cross, but with the government paying the costs. Legal practice may be regulated by a cartel of lawyers. Standards of safe practice may be determined by a body representing industry, professional expertise, government and 
public activists. Rather than trying to distinguish an entity called "the state" from what is "nonstate," the focus shifts to "the stateness of things" — that is, in what way is this ensemble of actors and pattern of practice "state-like"?

Public management, similarly, refocuses from "managing public organizations" to "managing public concerns" through the actors, organizations, and practices most likely to secure a good outcome: "making sense together" (Hoppe 1999; see, e.g., Moore's work on a "public value" focus-Colebatch 2010; Moore 1995).

Finally, scholars have to recognize that both practitioners and other academics are likely to be ambivalent about critical inquiry into the significance of these changes in the theorization of practice, and the links between work on public management and on the state. Practitioners recognize that while they might accomplish the outcome through negotiation, they need to be able to represent (re-present) it in a discourse of authoritative instrumental action, and academic analysts may also find it convenient to attribute function and intention to "the state."

\section{Public Management Research Is Missing the Big Questions-Donald F. Kettl}

Bubbling in the background of public management research is a huge puzzle: Are researchers spending far too little time on the really big questions in the field because of a growing instinct to drill ever deeper into ever smaller questions? Is public management neglecting the state and the large issues that are shaping governance throughout the world?

In a Public Administration Review article, Bradley E. Wright $(2015,797)$ applauds the progress that the field has made in resolving some of its fundamental questions. The reason, he argues, is that the field "has become much more scientific" in the last two generations, because of "increasing rigor in both the qualitative and quantitative research conducted in the field." Drilling deeper with better tools, Wright contends, has helped the field shake loose of the questions from Robert A. Dahl (1947) about whether the field ever could be truly a science. But in his analysis of a symposium at the University of Michigan, Andrew J. Hoffman (2015) points to "a crisis of relevance," especially in ensuring that scholars engage the fundamental questions that matter and write about them in ways that will have impact.

It is impossible to quibble with Wright's conclusion. The explosion of research in the field's journals-and the increase in the number of highly regarded journals-represents advances that Dahl and other critics of the 1940s and 1950s would scarcely have imagined. But it is also impossible to ignore the complaints of practitioners and theorists outside the field that public management is missing big trends and the potential for big impacts on big questions. Francis Fukuyama (2014), for example, has written a devastating critique arguing that many governments-most of all in the United States-are plagued by "political decay" that hinders their capacity to do what they promise. No matter what advances the field has made in becoming more scientific, that progress will matter little if the fundamental capacity of the state to deliver on its policies is in doubt, and if the field misses the chance to engage this debate.

Other big questions litter the landscape. New governance strategies-what some call "the fourth sector" (Sabeti 2009)—are emerging as government collaborates with the private and nonprofit sectors to create new strategies for producing social benefit. As Dahl himself might ask, who governs these collaborations? What kind of mechanisms will they create to deliver on their promises? How are they held accountable? What standards of transparency should they have? And, for that matter, what does "transparency" mean, since anything labeled "not transparent" is viewed as 
inherently wrong? Are there limits to what should be transparent, and to what degree? Should the costs of transparency matter? Then there is the argument for more "civic engagement" and "public participation." Are these unalloyed goods? Or do demands to open up the process create privileged opportunities for some interests to increase regulatory capture?

When Dahl criticized the field for its lack of scientific grounding, there was a counterbalance: The connection between practitioners and researchers was strong, and there was a vibrant sense at the time that the research bore directly on practical problems. One cost of the growing emphasis on science has been a literature increasingly impermeable to those outside the research community-and with an emerging policy-relevant literature growing beyond the professional journals, such as the work produced through the IBM Center for the Business of Government. This disjunction is happening at precisely the moment that the appetite for insights into delivering public services among policymakers, journalists, and those who care about governance has never been greater.

It is sometimes argued that the field has to build its scientific base before it can speak truth to power. There is no doubt that knowing what one is talking about is essential before trying to talk. But there is great value in listening carefully to policymakers about the questions to which they most need answers, and in trying to provide insights on the struggles that are most important. The launch of the Affordable Care Act, for example, struggled not only because of the political controversy surrounding it but also because top policymakers paid little attention to the administrative details. Management consultants jumped into the fray and turned the problem around in a remarkably short time. Public management research contributed little to the debate, before or after that disastrous launch.

It is also argued that it is hard to attack these big questions because many of them lack the data sets required for careful research. There are, however, invaluable data sets that have barely been tapped. For example, the Federal Employee Viewpoint Survey (FEVS), which the Office of Personnel Management conducts annually to gauge the views of government workers, offers vast potential for understanding how different strategies of leadership and different kinds of policy problems produce different impacts on employees-and vice versa-although far more needs to be done to help FEVS and other federal data sets feed theoretical advances (see Fernandez et al. 2015). A step back to ask which questions most need answers could help the field develop the new tools and data it needs to answer them, instead of focusing on questions defined by the tools at hand.

Perhaps most important, it is often argued that delving into these big questions is simply too risky for junior scholars, who need to publish to get tenure and who have the best opportunities to publish if they do workmanlike studies on existing questions using existing data sets. There is a powerful logic there, but it risks making the field ever narrower. Once trained in their harnesses, horses tend to work most easily in the same traces. If "big questions" are those left for the future, the future might well never come.

It is worth remembering that big careers have been made by young scholars asking big questions. A very promising 30-year-old scholar, James G. March, teamed in 1958 with future Nobel laureate Herbert Simon to write one of the great books of the field, Organizations (1958). Dahl was 32 when his challenge to the science of administration appeared. Big questions have often led to big careers.

For scholars interested in exploring big questions, moreover, there are lots of relatively unexplored data sets, like FEVS. At a time when government is starved for 
insight and committed to open data, opportunities for looking at big questions through the lens of careful data analysis are growing.

So what would it take to ask the big questions? First, public management scholars need to spend more time looking outside the field to understand the big trends shaping the world of governance. There is a fundamental paradox that one of the biggest questions facing public management-whether the practice of public management itself is in decay-is being asked and debated almost completely outside the field. The field needs to lean forward in defining its research agenda, even as it looks back to define holes in existing theory that need to be filled.

Second, those in the field need to think much more creatively about how to develop new research tools and how to develop new data sets on which to use them. Many government agencies have big puzzles, rich data, and not enough staff to analyze them. Partnerships, including memoranda of understanding, can open doors to manageable questions that need better research, which is far more likely to have an impact. We need to make better use of the data sets that exist, we need to develop new data sets to investigate important questions, and we need to make methodological advances, including in careful qualitative research, so our research is not limited to those puzzles structured through quantitative techniques.

Finally, those in the field need to think about how to mentor younger scholars to take these steps. Most of them came into public management with a keen interest in making government work better and with a taste for the important questions. It is not necessary to wring that out of them in the pursuit of a more scientifically grounded discipline. More established scholars in the field can frame discussions on the big questions, help younger scholars figure out how best to attack them, and then support these scholars when it comes time to write references in the tenure process.

There has never been a more exciting time in the history of governance and public management. Fundamental models, like authority and hierarchy, governed the practice of government for hundreds of years are under assault. New and untried models are rising to challenge them. We need more deep dives into existing theory to cement the propositions on which we build. But we surely need to encourage-indeed, to make it safe-for scholars, including younger ones, to ask the big questions. Those questions will not go away. They are reshaping governance. And they will reshape it without the insights of the field if public management does not engage them.

\section{Perverse Incentives and the Neglect of Big Questions-Robert F. Durant}

Calls for a return to academic research on "big questions" in public administration are important for the field to ponder. However, redressing the big questions problem requires more than pointing out to scholars that data sets are available for addressing big questions or that Herbert Simon or other luminaries of earlier eras earned their reputations by addressing them. Contemporary scholars in the United States face profoundly different professional incentive structures than those faced by Simon's cohort or by scholars even two decades ago. These changed incentive structures militate against studying big questions and threaten to "hollow" the study of public administration in the process (Durant 2014; Durant and Rosenbloom forthcoming).

Today's mutually reinforcing professional disincentives include: (1) methodological requirements for studying most big questions in public administration; (2) ticking tenure, promotion, and posttenure review clocks; (3) the overwhelming focus on adding statistical methods courses to $\mathrm{PhD}$ coursework at the cost of more big-pictureoriented classes; (4) stiffening competition for journal space; (5) the commodification 
of scholarly worth; and (6) the emphasis in research universities on getting major grants from foundations and other funding sources.

For starters, the interaction of large-scale, slow-moving, secular forces must be assessed to address many big questions in public administration. Questions regarding the changing nature of the state or the evolution of administrative reform movements demand longitudinal data on these properties, as well as on their changing sociopolitical, economic, demographic, cultural, and technological contexts. But gaps and inconsistent measures of variables in data sets are common on such timescales.

The econometric approaches involved in analyzing these data sets also pose major constraints on addressing big questions in public administration. Econometric analyses use what Chester Barnard called in The Functions of the Executive "cause-effect reasoning" and stress parsimony over complexity. However, studying big questions often requires what he called "pattern reasoning" (or recognition) amid administrative complexity. Econometric analyses can handle only a limited number of interaction terms, making pattern recognition on the scale necessary highly problematic. Consequently, research on big questions often depends on qualitative research that is more time consuming, requires process tracing over time, and is difficult to condense into journal articles without losing key explanatory context. This renders the analyses of existing data sets more attractive than creating new ones. Also more attractive is identifying questions in existing surveys such as the Federal Viewpoint Survey, which is collected for other purposes. These may approximate, but may not precisely operationalize, variables necessary for answering big questions. Time can also be seen as more wisely spent on developing multiple manuscripts using econometric analyses as quickly as possible for submission to journals as the promotion and tenure, annual productivity reports, and de facto posttenure review clocks tick down.

This tendency is reinforced by the expanding emphasis on econometric analyses in most PhD programs in the United States. One does what one is trained to do in $\mathrm{PhD}$ programs. These methodologies have made significant contributions to our understanding of public administration. However, the message sent to students in PhD programs with such a narrow focus is that econometric analyses are the epistemology of choice for making the reputations they seek. Perhaps this is true today, perhaps not, but it guarantees that it will be so in the future. Yet many big questions require qualitative analyses or mixed methods to address adequately.

Further marginalizing research on big questions is the staffing of schools of public affairs partly by fields such as economics that do not value books as much as articles. This is a decided change compared to their value in Simon's era. Others have moved toward economics' dissertation model of "three papers" rather than book-length dissertations. Thus, the allure-as well as the skills necessary to address big questions requiring the development of extended and empirically supported argumentsdiminishes. This is compounded by journal editors' understandable concerns over the allocation of precious space in journals. This does not mean that editors are biased against "big question" articles. But the publication decision "bar" is high because of the need to support claims made within the confines of journal page limitations.

In turn, the commodification of scholarly and professional worth today in citation counts adds disincentives for research on big questions. It also militates against anything but methodological and econometric innovation. Although leading research universities do not expect large numbers of citations from junior faculty, they increasingly require data on citations in promotion and tenure dossiers. Moreover, with Charles Dickens's "Mr. Gradgrind" seemingly the guardian of establishing the professional value of a person's scholarly reputation, faculty are incentivized to publish in well-trodden research areas so they can maximize citation counts. Granted, 
one might publish a "breakout" piece that becomes a classic in the field with unlimited citation prospects. But the odds of doing so are low compared to articles that add another "brick" to well-established research "walls."

Finally, as scoring grant money in sizable amounts from major public and private funders becomes yet another component of faculty evaluations, what these entities fund becomes part of the incentive structure for researchers. These funders tend not to focus on the big questions of public administration. Even those funding organizations geared toward improving public management tend to focus relatively small amounts of grants on microadministrative issues (e.g., the instrumental impact of enterprise management on agency collaboration) rather than the macrodynamics of public administration (Roberts 2009).

Reputations can and should be made by addressing the big questions in public administration. Yet as long as these sets of professional disincentives exist, U.S. scholars are likely to be cautious about pursuing research on big questions. A rethinking of these disincentives by the field is necessary. Otherwise, the ongoing hollowing of the field and the validity of our answers to its big questions will continue apace.

\section{References}

Abrams, Philip. 1988. "Notes on the Difficulty of Studying the State." Journal of Historical Sociology, 1 (1): 57-89.

Aguilar, Luis F. 2006. Gobernanza y Gestión Pública. Mexico City: FCE.

Ansell, Chris, Arjen Boin, and Ann Keller. 2010. "Managing Transboundary Crises: Identifying the Building Blocks of Effective Response System." Journal of Contingencies and Crisis Management 18 (4), 195-207.

Arellano, David (coord.). 2010. Más allá de la Reinvención del Gobierno. Mexico City: Miguel Ángel Porrúa-CIDE.

Bobbitt, P. 2002. The Shield of Achilles: War, Peace and the Course of History. New York: Alfred A. Knopf.

Boin, Arjen, Paul 't Hart, Eric Stern, and Bengt Sundelius. 2016. The Politics of Crisis Management. 2nd ed. Cambridge, UK: Cambridge University Press.

Cabrero, Enrique. 1997. Del Administrador al Gerente Público. Mexico City: INAP.

Campbell, John L., Joseph Rogers Hollingsworth, and Leon N. Lindberg, (eds). 1991. Governance of the American Economy. New York: Cambridge University Press.

Cejudo, Guillermo. 2015. "New Wine in Old Bottles: How New Democracies Deal with Inherited Bureaucratic Apparatuses: The Experiences of Mexico and Spain." In Public Administration, Vol. 5, ed. B. Guy Peters and Jon Pierre. London: Sage.

Colebatch, Hal K. 2010. "Making Sense of Governance." Policy and Society 33: 307-316.

. 2014. "Valuing Public Value: Recognizing and Applying Knowledge about the Policy Process." Australian Journal of Public Administration 69 (1): 66-78.

Dahl, Robert A. 1947. "The Science of Public Administration: Three Problems." Public Administration Review 7 (1): 1-11.

Dilulio John, Jr. 1998. "Recovering the Public Management Variable: Lessons from Schools, Prisons and Armies." International Journal of Public Administration 21 (6-8): 1147-1168.

Drechsler, W., and Tiina Randma-Liiv. 2015. "In Some Central and Eastern European Countries, Some NPM Tools May Sometimes Work: A Reply to Dan and Pollitt's 'NPM Can Work'." Public Management Review. Advance online publication. doi:10.1080/ 14719037.2015.1114137

Durant, Robert F. 2014. "Taking Time Seriously: Progressivism, the Business-Social Science Nexus, and the Paradox of American Administrative Reform." PS: Political Science E Politics 47 (1): 8-18.

Durant, Robert F., and David H. Rosenbloom. Forthcoming. "The Hollowing of Public Administration," American Review of Public Administration.

Elmore, Richard F. 1986. "Graduate Education in Public Management: Working the Seams of Government." Journal of Policy Analysis and Management 6 (1): 69-83. 
Fernandez, Sergio, William G. Resh, Tima Moldogaziev, and Zachary W. Oberfield. 2015. "Assessing the Past and Promise of the Federal Employee Viewpoint Survey for Public Management Research: A Research Symposium." Public Administration Review 75 (3): 382394.

Fukuyama, Francis. 2011. The Origins of Political Order: From Pre-human Times to the French Revolution. New York: Farrar, Straus and Giroux.

- 2014. "America in Decay." Foreign Affairs 93 (5): 3-26.

2015. Political Order and Political Decay: From the Industrial Revolution to the Globalization of Democracy. New York: Farrar, Straus and Giroux.

Gore, Albert. 1993. Creating a Government That Works Better and Costs Less. New York: Times Books.

Griffith, Ernest S. 1939. The Impasse of Democracy. New York: Harrison-Milton Books.

Hoffman, Andrew J. 2015. Academic Engagement in Public and Political Discourse: Proceedings of the Michigan Meeting. Ann Arbor: Michigan Publishing.

Hood, Christopher. 1991. "A Public Management for All Seasons?" Public Administration 69 (1): 3-20.

Hoppe, Robert. 1999. "Policy Analysis, Science and Politics: From 'Speaking Truth to Power' to 'Making Sense Together'." Science and Public Policy 26 (3): 201-210.

2010. The Governance of Problems. Puzzling, Powering, Participation. Bristol, UK: Policy Press.

Hou, Yilin, Anna Ya Ni, Ora-orn Poocharoen, Kaifeng Yang, and Zhirong J. Zhao. 2011. "The Case for Public Administration with a Global Perspective." Journal of Public Administration Research and Theory 21 (Suppl 1): i45-i51.

Jensen, Laura S. 2003. Patriots, Settlers, and the Origins of American Social Policy. Cambridge, UK: Cambridge University Press.

- 2008. "Government, the State, and Governance." Polity 40 (3): 379-385.

Joosse, Alexandra P. 2015. "Power in Collaborative Networks." Doctoral Dissertation, School of Government and Public Policy, University of Arizona.

Kettl, Donald F. 2002. The Transformation of Governance: Public Administration for Twenty-First Century America. Baltimore: Johns Hopkins University Press.

Ladeur, Karl-Heinz. 2004. "Globalization and Public Governance-A Contradiction?" In Public Governance in the Age of Globalization, ed. Karl-Heinz Ladeur. Aldershot, England: Ashgate.

Lam, Jermain T. M. 1997. "Transformation from Public Administration to Management: Success and Challenges of Public Sector Reform in Hong Kong." Public Productivity \& Management Review 20 (4): 405-418.

Long, Norton E. 1958. "The Local Community as an Ecology of Games." American Journal of Sociology 64 (3): 251-261.

Mann, Thomas E., and Norman J. Ornstein, 2013. It's Even Worse Than It Looks. New York: Basic Books.

March, James G., and Herbert A. Simon. 1958. Organizations. New York: Wiley.

Milward, Brinton H., and R. L. Breiger. 2014. "A Multi-Nodal World: Networks, Games and Narratives." Paper presented at the International Studies Association, Toronto, March 29.

Milward, Brinton H., and Keith G. Provan. 2000. "Governing the Hollow State." Journal of Public Administration Research and Theory 10: 359-379.

Milward, Brinton H., Keith G. Provan, Amy Fish, Kimberley R. Isett, and Kun Huang. 2010. "Governance and Collaboration: An Evolutionary Study of Two Mental Health Networks." Journal of Public Administration Research and Theory. 23: 229.

Moore, Mark H. 1995. Creating Public Value: Strategic Management in Government. Cambridge, MA: Harvard University Press.

Moynihan, Donald. (2012). "A Theory of Culture-Switching: Leadership and Red Tape during Hurricane Katrina." Public Administration 90 (4): 851-868.

Nettl, John P. 1968. "The State as a Conceptual Variable." World Politics 20 (4): 559-592.

Olsen, Johan P. 2006. "Maybe It Is Time to Rediscover Bureaucracy." Journal of Public Administration Research and Theory 16 (1): 1-24.

Pardo, María del Carmen. 2009. La modernización administrativa en México, 1940-2006. Mexico City: El Colegio de México.

Raadschelders, Jos C. N. 2003. Government: A Public Administration Perspective. Armonk, NY: M.E. Sharpe.

Rhodes, Roderick A. W. 1997. Understanding Governance. Maidenhead: Open University Press. 
Roberts, Alasdair. 2009. "The Path Not Taken: Leonard White and the Macrodynamics of Administrative Development." Public Administration Review 69 (4): 764-775.

. 2015. "The Nation-State: Not dead yet." The Wilson Quarterly (Summer). <http:// wilsonquarterly.com/quarterly/summer-2015-anage-of-connectivity/the-nation-state-notdead-yet/>.

Sabeti, Heerad. 2009. The Emerging Fourth Sector. Washington, DC: Aspen Institute.

Schmitt, Carl. 1922/1985. Political Theology. Chicago: The University of Chicago Press.

Schuck, Peter H. 2014. Why Government Fails So Often. Princeton, NJ: Princeton University Press.

Skinner, Quentin. 2008. Hobbes and Republican Liberty. New York: Cambridge University Press.

Smith, Rogers M. 1997. Civic Ideals: Conflicting Visions of Citizenship in U.S. History. New Haven, CT: Yale University Press.

Ulrich Beck. 2008. "Reframing Power in the Globalized World." Organization Studies 29 (5): 793-804.

Volcker Alliance. 2015. Research Shows Growing Number of Federal Government Breakdowns. Washington, DC: The Volcker Alliance.

Weick, Karl E. 1979. The Social Psychology of Organizing. 2nd ed. Reading, MA: AddisonWesley.

Wright, Bradley E. 2015. "The Science of Public Administration: Problems, Presumptions, Progress, and Possibilities." Public Administration Review 75 (6): 795-805.

Yates, Douglas T. 1977. "The Mission of Public Policy Programs: A Report on Recent Experience." Policy Sciences 8 (3): 363-373. 